\title{
LES LETTRES PHILOSOPHIQUES EN ANGLAIS OU L'ABONDANCE DE LA TRADUCTION PREMIERE
}

\author{
Guy Rooryck ${ }^{1}$ \\ Lieve Jooken $²$ \\ 1,2 Universiteit Ghent, Ghent, Belgium
}

Résumé : Le présent article confronte le texte anglais des Lettres philosophiques de Voltaire (Letters concerning the English Nation) paru en 1733 à trois traductions modernes dues respectivement à Ernest Dilworth (1961), à Leonard Tancock (1980) et à Prudence L. Steiner (2007). L'analyse porte en particulier sur les treizième et quatorzième lettres, consacrées l'une à John Locke, l'autre à une comparaison entre Descartes et Newton. La traduction ancienne, due à John Lockman, tranche par son ton incisif et met en relief, bien plus que les versions modernes, l'aspect séditieux de l'argumentation émise par Voltaire lorsqu'il évoque l'empirisme de Locke et la cosmologie de Newton. Le traducteur anglais contemporain des Lumières reproduit pleinement ce que Berman appelle la signifiance du texte original par une emphase fidèle au projet illocutoire de Voltaire. Grâce à sa "simultanéité historique" (Annie Brisset) le texte anglais de 1733 transmet avec force ce que Voltaire, voulant éviter les rets de la censure, exprime avec plus de retenue dans la version française. Reproduisant cet évitement de la parole, les traductions modernes ne portent plus en elles les marques subversives que, conformément au projet voltairien, Lockman avait au contraire amplifiées.

Mots clés : Voltaire; Lettres anglaises; Traduction au dix-huitième siècle; Emphase; Voix énarrative 


\title{
VOLTAIRE'S LETTRES PHILOSOPHIQUES IN ENGLISH: THE SEDITIOUS VOICE OF THE FIRST TRANSLATION
}

\begin{abstract}
This study confronts the English text of Voltaire's Lettres philosophiques (Letters concerning the English Nation), which appeared in 1733, with three modern translations by Ernest Dilworth (1961), Leonard Tancock (1980) and Prudence L. Steiner (2007). The analysis focuses in particular on the thirteenth letter, devoted to John Locke, and the fourteenth letter, which compares Descartes and Newton. Adopting a more incisive voice than the modern versions, the original English translation, attributed to John Lockman, invokes the seditious aspect of Voltaire's account of Locke's empiricism and Newton's cosmology in direct terms. In doing so, the contemporaneous Enlightenment translator reproduces what Berman calls the 'signifiance' of the original text as he explicitly emphasises Voltaire's illocutionary intent. Thanks to its historical simultaneity ("simultanéité historique", Annie Brisset) the 1733 English text therefore forcefully conveys the message that Voltaire expresses in more reticent censorship-wary terms in the French version. The modern translations, on the other hand, reproduce this more evasive voice and no longer transmit the marks of subversion, which Lockman amplifies defiantly.
\end{abstract}

Keywords: Voltaire; Lettres anglaises; Translation in the eighteenth century; Emphasis; Enarrative voice

\section{AS LETTRES PHILOSOPHIQUES EM INGLÊS OU A ABUNDÂNCIA DA PRIMEIRA TRADUÇÃO}

Resumo: O presente artigo confronta o texto inglês das Lettres philosophiques [Cartas filosóficas] de Voltaire (Letters concerning the English Nation) (1733) a três traduções modernas, de Ernest Dilworth (1961), Leonard Tancock (1980) e Prudence L. Steiner (2007). A análise se centra em particular sobre a décima-terceira e a décima-quarta cartas, uma consagrada a John Locke e a outra a uma comparação entre Descartes e Newton. A tradução antiga, de John Lockman, é cortante, devido a seu tom incisivo, e destaca bem mais que as versões modernas o aspecto sedicioso da argumentação de Voltaire ao invocar o empirismo de Locke e a cosmologia a de Newton. O tradutor contemporâneo ao Iluminismo reproduz plenamente o que Bergman chama de significância do texto original através de uma ênfase fiel ao projeto ilocucionário de Voltaire. Graças à "simultaneidade histórica" (Annie Brisset), o texto inglês de 
1733 transmite com vigor o que Voltaire, desejoso de evitar a censura, exprime de modo mais contido na versão francesa. Reproduzindo essa evasão da fala, as traduções modernas não trazem as marcas subversivas que, em conformidade ao projeto de Voltaire, Lockman havia, pelo contrário, ampliado.

Palavras-chave: Voltaire; Cartas inglesas; Tradução no século XVIII; Ênfase; Voz narrativa; Iluminismo

\section{Un original dédoublé : les Letters concerning the English Nation et les Lettres philosophiques}

Les questionnements autour de la retraduction relèvent du domaine que Genette a appelé la "transtextualité", c'est-à-dire de "tout ce qui met [un texte] en relation, manifeste ou secrète, avec d'autres textes" $(1982,7)$. Le présent article examine un cas de retraduction qui pour être particulier n'en comporte pas moins des enseignements qui ont le mérite de reconsidérer l'idée répandue selon laquelle face à une version originale unique, un hypotexte monolithique et immuable, les traductions successives se manifesteraient comme autant d' hypertextes multiples et variables dont la dernière mouture serait en outre par définition plus lisible que les versions antérieures, nécessairement défaillantes et obsolètes. L'ouvrage que nous abordons brièvement ici, les Lettres philosophiques de Voltaire, permet en effet d'une part de mettre en lumière le statut complexe de ce qui est censé être un texte "original" et d'autre part d'examiner si s'avère effective l'assertion d'Antoine Berman selon laquelle "[1]a retraduction surgit de la nécessité non certes de supprimer, mais au moins de réduire la défaillance originelle" (5).

Les lettres dites "anglaises" sont considérées comme le premier texte véritablement philosophique de Voltaire, en ce sens qu'il engage son auteur dans le combat des Lumières. D'emblée, par l'histoire de sa genèse, l'ouvrage met sous tension le rapport classique entre un texte source écrit dans une langue A qui engendrerait en un second temps un texte cible traduit dans une langue B. 
Un rappel rapide des faits s'impose. S'étant exilé entre 1726 et 1728 en Angleterre, suite à son altercation avec le chevalier de Rohan, Voltaire s'initie à la langue du pays. Il écrit un double Essay en anglais traitant des guerres de religion en France et de la poésie épique ${ }^{1}$, puis décide, comme il en fait part dans une lettre adressée (en anglais encore) à son ami Nicolas Thiriot, de rédiger une sorte de reportage sur les caractéristiques de la nation et la civilisation anglaises ${ }^{2}$. L'ouvrage finira par paraître en deux langues et connaitra un destin particulier et tumultueux dans sa version française: controversé il sera mis à l'index et brûlé par le parlement de Paris. C'est que, non sans avoir recours au ton parfois sarcastique, Voltaire chante surtout les louanges de la tolérance religieuse et politique de l'Angleterre, et qu'il s'ingénie ce faisant à exprimer en contre-point une critique acerbe de la société française catholique et absolutiste. Rentré en France, il relit ses notes, les retravaille entre 1728 et 1733 et opte finalement pour une série de vingt-quatre lettres censées écrites à Thiriot. Celui-ci devient son agent en Angleterre et est chargé de publier le texte à Londres en deux versions. Le livre est d'abord édité en anglais en 1733 sous le titre Letters concerning the English Nation ${ }^{3}$, puis, l'année suivante, Thiriot fait paraître sous une fausse adresse les Lettres écrites de Londres sur les Anglais et autres sujets ${ }^{4}$. Au même moment Voltaire charge sur le continent l'imprimeur rouennais Claude

\footnotetext{
${ }^{1}$ An Essay upon the Civil Wars of France and also upon the epick poetry of the European Nations, from Homer down to Milton. L'ouvrage paraît à Londres en 1728.

${ }^{2}$ Voltaire parle d'une unaccountable nation et fait part de son désir de voir Thiriot débarquer à Londres : You will see a nation fond of their liberty, learned, witty, despising life and death, a nation of philosophers, not but that there are some fools in England, every country has its madmen.[...] One day I will acquaint you with the character of this strange people. Voltaire à Nicolas Thiriot, 26 octobre 1726 (Correspondance, tome I, Paris: Gallimard (Pléiade) (1963): 187-189.)

${ }^{3}$ Letters concerning the English Nation by Mr. de Voltaire. London: Davis and Lyon, 1733.

${ }^{4}$ Lettres écrites de Londres sur les Anglais et autres sujets par M. D. $V^{* * *}$. A Basle [Londres: W. Bowyer], 1734.
} 
François Jore de diffuser une version à laquelle l'auteur ajoute une vingt-cinquième lettre s'attaquant à Pascal. Cette fois les Lettres sont qualifiées de "philosophiques" dans le titre".

Les deux textes londoniens édités par Thiriot contiennent une préface dont l'édition Jore de Rouen est exempte. Comme l'a constaté Lanson dans son édition qui a longtemps fait autorité "les deux Préfaces de Londres, anglaise et française, sont directement suggérées par Voltaire" (Voltaire / Lanson, xxxvi). Y prend la parole un éditeur anonyme (en fait Thiriot) qui évalue le texte et justifie sa publication. L'argumentaire péritextuel des deux versions s'accorde sur une prise de parole qui se fraie un chemin sur le mode de la prétérition: les lettres sont d'ordre privé, elles sont écrites pour un ami, "pas pour être publiques" (Préface, p. i), "not designed for the public" (Preface, p. iii). Mais l'impact préfaciel diffère; la version anglaise, longue de six pages alors que la française en compte à peine deux, mentionne à sept reprises explicitement le nom de Voltaire qui figure d'ailleurs aussi sur la page de titre. Le texte français n'insiste pas sur l'identité de M.D.V***, l'auteur devient dans la préface "une personne fort connue dans le monde". Le nom de Thiriot, absent en français, est explicitement mentionné en anglais comme un $\mathrm{ami}^{6}$ qui devient ainsi le narrataire explicite d'un ouvrage dont la préface affirme qu'il plaira au public anglais grâce au talent de l'auteur. Ce dernier, s'il n'est peut-être pas à même de déchiffrer entièrement les arcanes de la société anglaise, n'en offre pas moins des réflexions à la fois pertinentes et divertissantes à ses lecteurs grâce à l'ardeur ("the noble fïre", p. iv) de son style. Le texte français appuie au contraire la prétérition, le livre n'aurait pas dû paraître, son auteur a tout fait pour en arrêter l'impression jugée dangereuse, mais comme certains libraires étaient sur le point "de faire traduire en français la traduction anglaise de ces lettres” (p. ii), l'éditeur s'est décidé à passer outre l'interdit de

${ }^{5}$ Lettres philosophiques par M. de V.... Amsterdam: E. Lucas [Rouen: Jore], 1734. ${ }^{6}$ [The Letters] are the Result of the Author's Complacency and Friendship for Mr. Thiriot... (Preface, iii). 
l'auteur. La liberté de ton avancée dans la version anglaise incite à la publication des Letters concerning the English nation, alors que, quoiqu' "écrites librement" et "de Londres", les Lettres sur les Anglais contiennent en raison même de cette franchise un risque dont il est dit en français que l'auteur rechigne à le prendre. Autre constatation, le texte anglais ne se présente nulle part comme une traduction tandis que le texte français se donne comme un original dont le manuscrit a été traduit en anglais.

Original et traduction sont ici difficilement dissociables et ont un destin lié. En 1967 Harcourt Brown, constatant les libertés qui apparaissent dans le texte anglais par rapport à la version française, conclut après analyse que Voltaire aurait écrit quatorze lettres sur vingt-quatre directement en anglais avant de les autotraduire librement en français, alors que les autres, en général plus tardives, auraient été rédigées tantôt en deux langues pour trois d'entre elles, tantôt pour sept autres, en français pour ensuite être traduites par John Lockman, qui avait déjà fourni en 1732 une version anglaise de La Henriade. Patrick Lee et Nicolas Cronk, l'actuel directeur de la Voltaire Foundation, ont émis en 2001 de sérieux doutes sur cette hypothèse et avancé des arguments en faveur d'un original français que Lockman aurait traduit en entier sous l'éventuelle supervision de Voltaire. Quoi qu'il en soit, le texte original est en quelque sorte double; la parution anglaise est première et joue un rôle dans la manière dont Voltaire veut échapper à la censure, mais le texte français paru à Rouen chez Jore sous le titre Lettres philosophiques présente des variantes qui lui sont propres et contient la lettre sur Pascal, de sorte qu'il s'agit d'une version qui peut se prétendre elle aussi originale. Le texte français des Lettres connaîtra plusieurs métamorphoses, après quelques rééditions clandestines et contrefaçons, il est fragmenté tout au long du XVIIIe siècle d'abord par Voltaire lui-même, puis dans des éditions de ses Euvres où les Lettres sont disséminées dans des volumes de Mélanges. C'est dans cette forme fragmentée qu'elles sont aussi traduites par Tobias Smollett et Thomas Francklin dans le treizième volume des Works of $M$. de Voltaire paru en 1762. 
En France, la célèbre édition Kehl initiée à la fin du XVIIIe siècle par Beaumarchais reprend toujours ces mêmes textes disséminés et il faut attendre 1818 avant qu'Adrien Beuchot finisse par rééditer les Lettres anglaises en leur entité autonome, mais à partir de l'édition londonienne de Thiriot. En 1909 Lanson leur préfère la version Jore que Voltaire avait supervisée et qui contenait la vingtcinquième lettre sur Pascal. Lanson établit le texte des Lettres, - désormais à nouveau philosophiques, - à partir d'une étude philologique minutieuse. Sa version, de nombreuses fois rééditées, sert de base encore aujourd'hui aux éditions modernes, Pléiade comprise. Enfin, en 2017, Nicholas Cronk devrait faire paraître une nouvelle édition critique des Lettres dans la monumentale édition des Euvres Complètes éditées à la Voltaire Foundation d'Oxford, contenant pour la première fois dans un même volume les Lettres philosophiques de 1734 et la version anglaise de 1733.

Résumons. Du côté français d'abord. Les éditions du XXe siècle partent toutes de l'édition Jore établie par Lanson et ajoutent quantité de documents au texte d'origine. Introduction, chronologie, bibliographie, variantes, notes érudites, mais aussi bon nombre de documents d'époque qui viennent enrichir le texte initial. Ce qui relevait au XVIIIe siècle encore de ce que Genette appelle l'épitexte, c'est-à-dire des extraits de journaux, des premiers jets, des fragments de correspondance se rapportant au texte central, mais demeurant à l'extérieur du volume proprement dit, s'intègre désormais dans l'appareil péritextuel des éditions modernes, donnant à celles-ci un aspect s'éloignant du texte d'origine qui semble par contraste relativement court tant sa part s'amenuise par rapport au nombre total des pages. Ainsi les Lettres proprement dites s'étendent sur à peine la moitié des 352 pages de l'édition Garnier Flammarion (GF) fournie en 1996 par Gerhardt Stenger et ne font plus que 120 pages sur un volume en contenant 604 dans l'édition des Classiques Garnier (CG) d'Olivier Ferret et Antony McKenna paru en 2000. L'épitexte s'est fait péritexte afin de permettre au lecteur de mieux appréhender les Lettres dans leur enjeu culturel et historique d'origine. 
Voyons maintenant la publication des Lettres outre-Manche. Trois cas de figure sont à distinguer: premièrement la publication initiale de 1733 en anglais qui a été republiée aux XIXe et XXe siècles, et en 1994 pour la dernière fois par Nicholas Cronk; deuxièmement la traduction de Smollett \& Francklin à partir des Mélanges, traduction rééditée entre autres en 1901 et enfin, troisièmement, plus récentes, les traductions et retraductions anglaises faites celles-ci à partir du texte français de l'édition Jore / Lanson des Lettres philosophiques. Ce sont ces derniers textes qui nous retiendront dans la suite de cet article.

Les traductions d'Ernest Dilworth (D), de Leonard Tancock (T) et de Prudence Steiner (S) sont toutes trois encore disponibles sur le marché; elles datent respectivement de 1961, 1980 et 2007; les deux premières ont été rééditées en 2003 et 2005 . Toutes trois partent explicitement de l'édition Jore. Dilworth et Tancock mentionnent Lanson, Dilworth avec déférence, Steiner se réclame de l'édition Deloffre parue chez Gallimard qui s'appuie elle aussi sur Lanson. $\mathrm{Si}$ les trois traducteurs signalent par ailleurs l'existence de la version anglaise de 1733, Dilworth est le seul à explicitement nommer John Lockman. Dilworth et Steiner parlent d'une "first translation"; Steiner précise même l'avoir consultée, Tancock se contente de parler d'une "English version". Le texte des Lettres paraît par ailleurs sous des titres différents, comme on peut le voir dans le tableau ci-dessous :

\begin{tabular}{|c|c|c|c|}
\hline & $\begin{array}{l}\text { Titre texte } \\
\text { cible }\end{array}$ & $\begin{array}{l}\text { Référence au texte } \\
\text { source }\end{array}$ & $\begin{array}{l}\text { Référence à la } \\
\text { version anglaise de } \\
1733\end{array}$ \\
\hline $\begin{array}{l}\text { DILWORTH } \\
1961\left(2003^{7}\right)\end{array}$ & $\begin{array}{l}\text { Philosophical } \\
\text { Letters (Letters } \\
\text { Concerning } \\
\text { the English } \\
\text { Nation) }\end{array}$ & $\begin{array}{l}\text { The text used as } \\
\text { the base for this } \\
\text { translation is that of } \\
\text { Jore (Rouen, 1734) } \\
\text { as established from } \\
\text { Gustave Lanson. } \\
\text { (p. xv) }\end{array}$ & $\begin{array}{l}\text {...the book first } \\
\text { appeared in an } \\
\text { English translation } \\
\text { by John Lockman } \\
\text { (p. vii) }\end{array}$ \\
\hline
\end{tabular}

L'édition de 2003 (Mineola: Dover) est une réimpression à l'identique de l'édition de 1961 (Indianapolis: Bobbs-Merrill)

Cad. Trad., Florianópolis, v. 39, no 1, p. 94-116, jan-abr, 2019. 


\begin{tabular}{|c|c|c|c|}
\hline $\begin{array}{l}\text { TANCOCK } \\
1980 \\
\left(2005^{8 * *}\right)\end{array}$ & $\begin{array}{l}\text { Letters on } \\
\text { England }\end{array}$ & $\begin{array}{l}\text {...fortunately in } \\
\text { this case the work } \\
\text { of deciding on } \\
\text { a definitive text } \\
\text { has been done by } \\
\text { Gustave Lanson in } \\
\text { his masterly edition. } \\
\text { [...] [He] uses the } \\
\text { first French edition } \\
\text { published in } 1734 \\
\text { by Jore in Rouen. } \\
\text { (p. 19) }\end{array}$ & $\begin{array}{l}\text { an English version, } \\
\text { Letters concerning } \\
\text { the English Nation by } \\
\text { M. de Voltaire, ha[s] } \\
\text { appeared in London } \\
\text { in 1733. (p. 8) }\end{array}$ \\
\hline $\begin{array}{l}\text { STEINER } \\
2007\end{array}$ & $\begin{array}{l}\text { Philosophical } \\
\text { Letters, } \\
\text { Or Letters } \\
\text { Regarding the } \\
\text { English Nation }\end{array}$ & $\begin{array}{l}\text { The French text is } \\
\text { the one published } \\
\text { by Gallimard, with } \\
\text { notes prepared by } \\
\text { Frederic Deloffre } \\
\text { (1986). It is the text } \\
\text { published originally } \\
\text { by Jore in 1734. (p. } \\
\text { xxi) }\end{array}$ & $\begin{array}{l}\text { I had have the } \\
\text { benefit of consulting } \\
\text { the first English } \\
\text { translation of the } \\
\text { Philosophical Letters, } \\
\text { which appeared in } \\
\text { London in } 1733 \text {, } \\
\text { shortly before the } \\
\text { first French edition } \\
\text { appeared.(p. xxi) }\end{array}$ \\
\hline
\end{tabular}

\section{Il me faut déguiser à Paris ce que je ne pourrai dire trop fortement à Londres}

Examinons à présent les lettres XIII et XIV consacrées la première à Locke et la seconde à une comparaison entre Newton et Descartes. Elles figurent toutes deux parmi la série de textes qui ont avec certitude été écrits dès l'origine en français (GF, 65; CG, 14) $)^{9}$. La lettre sur Locke occupe une place particulière car Voltaire s'y est repris à deux fois avant de la publier sous sa forme

\footnotetext{
${ }^{8}$ La réimpression de 2005 chez Penguin Books reprend telles quelles la traduction et l'introduction de la publication de 1980; y sont ajoutées une chronologie et une nouvelle bibliographie en fin de volume.

${ }^{9}$ GF: édition Garnier-Flammarion; CG: édition des Classiques Garnier. Les caractères gras et les italiques dans les exemples et les citations sont du fait des auteurs de l'article.
} 
définitive. Dans une lettre souvent citée à son ami Jean Baptiste Formont, il précise "Je suis obligé de changer tout ce que j'avais écrit à l'occasion de $\mathrm{M}$. Locke, parce qu'après tout je veux vivre en France. [...] Il me faut déguiser à Paris ce que je ne pourrai dire trop fortement à Londres (CG, 420). Il y aborde en effet la délicate question de la nature de l'âme et risque de se mettre à dos tous les théologiens du royaume de France et de Navarre. "Il hésite", commentent les éditeurs de la collection des Classiques Garnier "entre l'audace provocatrice et le désir d'éviter la censure" (CG, 421). Or l'audace provocatrice peut se manifester à Londres, où les déguisements parisiens ne sont pas de mise.

Arrêtons-nous un instant à l'instance traductrice qui se superpose en filigrane à l'instance énonciative du texte d'origine. La voix du traducteur relève du mode de l'hybridité, car elle est à la fois réceptrice du texte source et émettrice du texte cible. Afin de cerner la spécificité de cette instance médiatrice du traducteur et d'en déceler les traces, nous la nommons dans nos publications la voix énarrative en référence à l'ancienne enarratio des Anciens, cette lecture explicative qui interprète et expose les difficultés d'un texte. Dans la traduction de 1733, cette voix énarrative souligne et consolide dans sa fonction argumentative les idées plus en retenue du texte original qui doit se frayer un chemin sinueux ou ondoyant en raison de la censure française. Dans son ouvrage The Spread of Novels, Helen McMurran montre combien au siècle des Lumières la traduction relève de ce que les Anciens appelaient 1' "inventio", une activité créatrice qui permet d'interpréter ce qu'il est convenu d'appeler les "infidélités" des traductions de l'époque comme une prolongation de certaines figures de rhétorique. Ainsi les suppressions et ajouts sont-ils conformes aux procédés de la brevitas ou de la concision et de l'amplificatio, ou de l'emphase. Cette dernière convient à merveille pour renforcer l'audace des idées neuves, et les traductions anglaises de textes philosophiques français contemporains y ont volontiers recours comme nous avons eu l'occasion de le démontrer dans des traductions de La Mettrie 
ou de Rousseau ${ }^{10}$. Dans les retraductions modernes en revanche la voix énarrative est bien plus neutre, elle reste au plus près du texte français dont elle reprend la retenue, le "déguisement" dont Voltaire parle dans sa correspondance, s'éloignant ainsi de la force illocutoire à proprement parler philosophique du texte qui incite à ébranler les valeurs de la société française de l'époque.

Remarquons tout d'abord que la version de 1733 reprend un point de vue plus "anglais" que les retraductions modernes, comme le prouve par exemple cet extrait du début de la Lettre XIV.

A Paris on voit l'univers composé de tourbillons, de matière subtile; à Londres on ne voit rien de cela. Chez nous [Jore > < Thiriot : Chez vous], c'est la pression de la lune qui cause le flux de la mer; chez les Anglais, c'est la mer qui gravite vers la Lune. Chez vos Cartésiens, tout se fait par une impulsion qu'on ne comprend guère; chez $\mathbf{M}$. Newton c'est par une attraction dont on ne connaît pas mieux la cause. A Paris, vous vous figurez la terre faite comme un melon; à Londres elle est aplatie des deux côtés. (GF,146)

At Paris the Universe is seen, compos'd of Vortices of subtile Matter, but nothing like it is seen in London. In France, 'tis the Pressure of the Moon that causes the Tides; but in England 'tis the Sea that gravitates towards the Moon. According to your Cartesians, every Thing is perform'd by an Impulsion, of which we have very little Notion; and according to Sir Isaac Newton, 'tis by an Attraction, the Cause of which is as much unknown to us. At Paris you imagine that the Earth is shap'd like a Melon, or of an oblique Figure; at London it has an oblate one. (1733 (Cronk), 61)

${ }^{10}$ La voix énarrative subsume réception et émission à travers un filtre interprétatif. Sur la voix énarrative du traducteur, voir Jooken, Lieve \& Rooryck, Guy "The Freedom of Expressing One's Ideas. Translating La Mettrie." The Translator 17, 2 (2011): 233-254; Rooryck, Guy \& Jooken, Lieve "Le péritexte des traductions anglaises du Discours sur les Sciences et les Arts de Jean-Jacques Rousseau: la voix énarrative du traducteur" Meta LVIII, 3, (2013) : 589-606 et enfin "Elie Luzac et L'homme plus que machine (1748)." Cadernos de Tardução, 38, 1 (2018): 197-225. 


\begin{tabular}{|c|c|c|}
\hline $\begin{array}{l}\text { In Paris one sees the } \\
\text { universe composed } \\
\text { of vortices of subtile } \\
\text { matter; in London one } \\
\text { sees nothing of the } \\
\text { sort. With us, it's the } \\
\text { pressure of the moon } \\
\text { that causes the rising } \\
\text { of the tide; with the } \\
\text { English, it's the see } \\
\text { gravitating toward } \\
\text { the moon. According } \\
\text { to your Cartesians, } \\
\text { everything is done by } \\
\text { means of an impulse } \\
\text { that is practically } \\
\text { incomprehensible; } \\
\text { according to Mr. } \\
\text { Newton it is by a kind } \\
\text { of attraction, the reason } \\
\text { for which is no better } \\
\text { known. In Paris you } \\
\text { picture the earth as } \\
\text { shaped like a melon; in } \\
\text { London it is flattened on } \\
\text { both sides. (D, } 60 \text { ) }\end{array}$ & $\begin{array}{l}\text { In Paris they see the } \\
\text { universe as composed } \\
\text { of vortices of subtle } \\
\text { matter, in London they } \\
\text { see nothing of the kind. } \\
\text { For us it is the pressure } \\
\text { of the moon that causes } \\
\text { the tides of the sea; } \\
\text { for the English it is } \\
\text { the sea that gravitates } \\
\text { towards the moon. } \\
\text { For your Cartesians, } \\
\text { everything is moved } \\
\text { by an impulsion you } \\
\text { don't understand, for } \\
\text { Mr. Newton it is by } \\
\text { gravitation, the cause of } \\
\text { which is hardly better } \\
\text { known. In Paris you see } \\
\text { the earth shaped like a } \\
\text { melon; in London it is } \\
\text { flattened on two sides. } \\
\text { (T, 68) }\end{array}$ & $\begin{array}{l}\text {..; in Paris, they } \\
\text { imagine a universe } \\
\text { composed of vortices } \\
\text { of subtle matter; } \\
\text { in London none of } \\
\text { this; we think it is } \\
\text { the pressure of the } \\
\text { moon that causes the } \\
\text { fluctuations of the } \\
\text { tides; the English } \\
\text { believe that the ocean } \\
\text { gravitates toward the } \\
\text { moo. Your Cartesians } \\
\text { believe that everything } \\
\text { happens by an impulse } \\
\text { that one scarcely } \\
\text { understands; for Mr. } \\
\text { Newton, the cause is } \\
\text { an attraction whose } \\
\text { cause is no better } \\
\text { understood. In Paris, } \\
\text { the earth is shaped like } \\
\text { a melon; in London, } \\
\text { it is flattened at both } \\
\text { sides. (S, } 47 \text { ) }\end{array}$ \\
\hline
\end{tabular}

La lecture de l'édition Jore dit “chez nous”, alors que l'édition Thiriot indique "chez vous" pour renvoyer à la France, présentant ainsi une plus grande cohérence avec le texte, puisque Voltaire épouse partout ailleurs un point de vue londonien quand il écrit “chez vos Cartésiens" et “A Paris, vous vous figurez". L'édition anglaise de 1733 épouse la cohérence d'un point de vue anglais, aucune première personne, en revanche un "your Cartesians" et un "you imagine" qui dissocient l'auteur des Français, alors que les trois versions modernes optent (conformément à l'édition Jore) pour un décalage dans le texte, passant pour désigner la France d'une première personne du pluriel "with us", "for us" ou "we 
think" à une deuxième dans "your Cartesians", "you picture" ou "you see". De même, dans la lettre XIII, "nos pères de l'Eglise" devient en 1733 "the Fathers of the Church", sans le possessif qui ancre la référence dans la culture catholique alors que toutes les versions modernes maintiennent le possessif dans "our Fathers of the Church". L'évocation de Malebranche dans la même lettre fait l'impasse dans la version anglaise contemporaine sur son appartenance à l'ordre de l'Oratoire et se contente d'un "Father Malbranche", alors que les traducteurs modernes mentionnent toutes "of the Oratory".

Berman oppose dans son article sur la retraduction la pauvreté et le manque qui caractériseraient les premières traductions à l'abondance et à la profusion de ce qu'il appelle "la grande retraduction", qui surviendrait à un moment favorable qu'il qualifie de kaïros $(1990,6)$. Or il se trouve que pour certaines traductions philosophiques anglaises des Lumières, - celle de L'homme machine de La Mettrie ou de L'Emile de Rousseau par exemple, - l'abondance et la profusion se produisent dans une contemporanéité à la production originale. Les versions anglaises de l'époque lâchent en effet la bride de la censure qui enfreint la libre expression dans le régime absolutiste français. Les retraductions modernes reproduisent en revanche avec prudence les contraintes du déguisement du texte d'origine.

L'extrait suivant de la Lettre XIV qui retrace le départ de Descartes pour la Hollande en fait foi; le texte de 1733 brille par le soulignement des idées développées dans des syntagmes bien plus longs que dans la version originale, qui se voit respectée strictement dans les versions modernes:

Il crut longtemps qu'il était nécessaire de fuir les hommes, et surtout sa patrie, pour philosopher en liberté. Il avait raison; les hommes de son temps n'en savaient pas assez pour l'éclaircir, et n'étaient guère capables que de lui nuire. (GF, 148)

He was a long Time of Opinion, that it would be necessary for him to fly from the Society of his Fellow Creatures, an especially from his native 
Country, in order to enjoy the Happiness of cultivating his philosophical Studies in full Liberty. Des Cartes was very right, for his Contemporaries were not knowing enough to improve and enlighten his Understanding, and were capable of little else than of giving him Uneasiness. $(1733,63)$

\begin{tabular}{|l|l|l|}
\hline $\begin{array}{l}\text { For a long time he } \\
\text { believed that in order } \\
\text { to philosophize freely } \\
\text { he would have to escape } \\
\text { from society, and } \\
\text { especially from his native } \\
\text { country. He was right; } \\
\text { the men of his time knew } \\
\text { too little to help him } \\
\text { clarify his ideas, and } \\
\begin{array}{l}\text { were in fact capable of } \\
\text { little more than doing } \\
\text { him harm. (D, 62) }\end{array}\end{array}$ & $\begin{array}{l}\text { For a long time he } \\
\text { believed it necessary to } \\
\text { meid the company of } \\
\text { own country, so as to } \\
\text { of his time did not know } \\
\text { enough to enlighten } \\
\text { him, and could scarcely } \\
\text { do anything but harm } \\
\text { him. (T, 69) }\end{array}$ & $\begin{array}{l}\text { He thought for a } \\
\text { long while that, to } \\
\text { philosophize freely, } \\
\text { he had to fly from } \\
\text { mankind and especially } \\
\text { from his country. He } \\
\text { was right; the men of } \\
\text { his time knew too little } \\
\text { to enlighten him and } \\
\text { were at best able only } \\
\text { to harm him. (S, 48 })\end{array}$ \\
\end{tabular}

Ce procédé de l'emphase est omniprésent dans le texte de 1733, comme encore par exemple dans ce fragment de la Lettre sur Locke qui démontre avec ironie que Dieu est fort capable de créer la pensée comme produit de la matière :

Le superstitieux vient à son tour et dit qu'il faut brûler, pour le bien de leurs âmes, ceux qui soupçonnent qu'on peut penser avec la seule aide du corps. Mais que diraient-ils si c'étaient eux-mêmes qui fussent coupables d'irréligion ? En effet, quel est l'homme qui osera assurer, sans une piété absurde, qu'il est impossible au Créateur de donner à la matière de la pensée et du sentiment. (V, 135-136)

The superstitious Man come afterwards, and declares, that all those must be burnt for the Good of their Souls, who so much as suspect that 'tis possible for the Body to think without any foreign Assistance. But what would these people say should they themselves be prov'd irreligious ? And, indeed, what Man can presume to assert, without being guilty at the same Time of the greatest Impiety, that 'tis impossible for the Creator to form Matter with Thought and Sensation? (1733, 58-59). 


\begin{tabular}{|c|c|c|}
\hline $\begin{array}{l}\text { Then, in his turn, } \\
\text { comes the superstitious } \\
\text { man, and he says that } \\
\text { those who suspect that } \\
\text { thought is possible } \\
\text { with the sole aid of the } \\
\text { body ought to be burnt } \\
\text { for the good of their } \\
\text { souls. But what would } \\
\text { such people say if it } \\
\text { were they themselves } \\
\text { to assert, without an } \\
\text { absurd impiety that it } \\
\text { is impossible for the } \\
\text { Creator to give thought } \\
\text { and feeling to matter! } \\
\text { (D, 57) }\end{array}$ & $\begin{array}{l}\text { The superstitious come } \\
\text { in their turn and say } \\
\text { that those who suspect } \\
\text { that one can think } \\
\text { with the body alone } \\
\text { should be burnt for the } \\
\text { good of their souls. But } \\
\text { what would they say } \\
\text { if it were themselves } \\
\text { who were guilty of } \\
\text { irreligion? And indeed } \\
\text { what kind of man will } \\
\text { dare to affirm, without } \\
\text { absurd impiety, that } \\
\text { it is impossible for } \\
\text { the Creator to endow } \\
\text { matter with thought and } \\
\text { feeling? (T, 66) }\end{array}$ & $\begin{array}{l}\text { The superstitious come } \\
\text { next and say that we } \\
\text { must, for the sake } \\
\text { of their souls, burn } \\
\text { those who suspect that } \\
\text { one can think with } \\
\text { the body alone. But, } \\
\text { what would they say } \\
\text { if it were they to be } \\
\text { condemned for heresy? } \\
\text { Indeed, unless he was } \\
\text { possessed by impious } \\
\text { folly, who would } \\
\text { dare to assert that the } \\
\text { Creator is incapable of } \\
\text { giving to matter both } \\
\text { thought and feeling? } \\
\text { (S, 44) }\end{array}$ \\
\hline
\end{tabular}

La voix argumentative du traducteur anglais de 1733 se fait entendre avec force dans un passage qui insiste sur les mérites de Locke: plutôt que de recourir aux mots "raison" ou "entendement" elle affirme que Locke étudie l'âme dans sa pleine humanité qui relève de l'intelligence qui est la partie complémentaire du corps matériel étudié par l'anatomiste. Le caractère prétendument divin de l'âme fait place ici à son humaine nature et reprend en écho l'adjectif qui figure dans le titre du maître-ouvrage du philosophe, An Essay concerning human understanding. Le processus qui permet à Locke de comprendre les mécanismes de l'entendement est décrit un peu plus loin dans le texte comme indépendant de toute intervention divine au syntagme nominal français " [il consulte] la conscience de sa pensée" se substitue une formulation verbale bien plus forte, - "the being conscious that he himself thinks", - qui, contrairement aux traductions modernes met en exergue l'émergence de la pensée empirique. 


\begin{tabular}{|c|c|c|}
\hline \multicolumn{3}{|c|}{$\begin{array}{l}\text { Locke a développé à l'homme la raison humaine, comme un excellent } \\
\text { anatomiste explique les ressorts du corps humain. }(\mathrm{GF}, 132)\end{array}$} \\
\hline \multicolumn{3}{|c|}{$\begin{array}{l}\text { Mr. Locke has display'd the human Soul, in the same Manner as an excellent } \\
\text { Anatomist explains the Springs of the human Body. }(1733,56)\end{array}$} \\
\hline $\begin{array}{l}\text { Locke has unfolded } \\
\text { to man the nature of } \\
\text { human reason as a } \\
\text { fine anatomist explains } \\
\text { the powers of the body. } \\
(\mathrm{D}, 54)\end{array}$ & $\begin{array}{l}\text { Locke has expounded } \\
\text { human understanding } \\
\text { to mankind as an } \\
\text { excellent anatomist } \\
\text { explains the mechanism } \\
\text { of the human body. } \\
(\mathrm{T}, 63)\end{array}$ & $\begin{array}{l}\text { ned human } \\
n \text { as an } \\
\text { omist } \\
\text { nechanism } \\
\text { ly. (S, } 42\end{array}$ \\
\hline \multicolumn{3}{|c|}{$\begin{array}{l}\text {;...il [Locke] consulte surtout son propre témoignage, la conscience de sa } \\
\text { pensée. }(\mathrm{GF}, 132)\end{array}$} \\
\hline \multicolumn{3}{|c|}{$\begin{array}{l}\text { Above all he consults himself; the being conscious that he himself thinks. } \\
(1733,56)\end{array}$} \\
\hline $\begin{array}{l}\text { Above all, he consults } \\
\text { his own experience, the } \\
\text { consciousness of his } \\
\text { own thought. }(D, 54)\end{array}$ & $\begin{array}{l}\text {... he consults especia } \\
\text { his own experience, } t \\
\text { consciousness of his } \\
\text { thought. }(T, 64)\end{array}$ & $\begin{array}{l}\ldots \text { and above all he } \\
\text { paid attention to his } \\
\text { own observations, } \\
\text { the awareness of his } \\
\text { own ideas. }(S, 42)\end{array}$ \\
\hline
\end{tabular}

Dans la prolongation de ce discours empirique, un passage sur la matérialité de l'âme fait bien ressortir dans l'édition ancienne l'ironie de Voltaire lorsqu'il convoque à la rescousse certains pères de l'église qui auraient prétendu que l'âme n'était pas de nature divine, comme l'avait par exemple clairement défendu Malebranche au XVIIe siècle, mais de nature humaine. Dans la version de 1733 "humaine" n'est pas un simple qualificatif comme dans les éditions anglaises modernes qui rangent l'âme humaine au côté de Dieu et des anges, mais fait bel et bien pendant de façon attributive aux anges et aux dieux qui eux sont "corporels":

Quant à nos pères de l'Eglise, plusieurs dans les premiers siècles ont cru l'âme humaine, les anges et les dieux corporels. GF, 131)

What regard to the Fathers of the Church, several in the primitive Ages believ'd that the Soul was human, and the Angels and God corporeal. $(1733,55)$ 


\begin{tabular}{|l|l|l|}
\hline $\begin{array}{l}\text { As for our Fathers of } \\
\text { the Church, several } \\
\text { of them in the earlier } \\
\text { centuries believed } \\
\text { the human soul, } \\
\text { the angels, and } \\
\begin{array}{l}\text { God himself to be } \\
\text { corporeal. }(\mathrm{D}, 53)\end{array}\end{array}$ & $\begin{array}{l}\text { As for our Fathers of } \\
\text { the Church, several of } \\
\text { them in the earliest times } \\
\text { believed the human } \\
\text { soul, the Angels and } \\
\text { God were corporal. }(T,\end{array}$ & $\begin{array}{l}\text { As for our Church } \\
\text { fathers, many in the } \\
\text { first centuries believed } \\
\text { that the human soul, } \\
\text { the Angels and God } \\
\text { were corporeal. }(\mathrm{S}, 41)\end{array}$ \\
\hline
\end{tabular}

En 1733, il est ainsi dit fortement à Londres ce qu'il faut déguiser à Paris, conformément au projet voltairien. En termes bermaniens, la traduction première reconstitue ainsi la signifiance $\mathrm{du}$ texte original, alors que les retraductions modernes inscrivent leur économie dans un espace langagier bien plus restreint. Que les Letters concerning the English Nation de 1733 demeurent le kaïros ${ }^{11}$ des Lettres philosophiques se confirme encore dans la patine du texte qu'expérimente également le lecteur de la version française. L'époque se fait entendre dans le texte ancien et lui donne son ampleur temporelle par l'entremise de détails qui disparaissent dans le sage réajustement des retraductions modernes. Ainsi les mots latins "plenum" et "vacuum" font retentir avec force la polémique qui opposait les vortex cartésiens à la gravitation newtonienne :

Un Français qui arrive à Londres trouve les choses bien changées en philosophie comme dans tout le reste. Il a laissé le monde plein, il le trouve vide. $(\mathrm{GF}, 146)$

A Frenchman who arrives in London, will find Philosophy, like everything else, very much chang'd there. He had left the World a plenum, and he now finds it a vacuum. $(1733,61)$

\begin{tabular}{|c|c|c|}
\hline $\begin{array}{l}\text { A Frenchman arriving } \\
\text { in London finds quite a } \\
\text { change, in philosophy as } \\
\text { in all else. Behind him }\end{array}$ & $\begin{array}{l}\text { A Frenchman arriving } \\
\text { in London finds things } \\
\text { very different, in } \\
\text { natural science as in }\end{array}$ & $\begin{array}{l}\text { A Frenchman arriving } \\
\text { in London finds changes } \\
\text { in philosophy as in other } \\
\text { matters. He left }\end{array}$ \\
\hline
\end{tabular}

11 C'est ainsi que Berman qualifie "le moment favorable" $(1990,6)$ d'une traduction abondante; loin d'être une "introduction" à la pensée voltairenne, le texte anglais de 1733 l'investit, la prolonge et la propage.

Cad. Trad., Florianópolis, v. 39, nº 1, p. 94-116, jan-abr, 2019. 


\begin{tabular}{|l|l|l|}
\hline $\begin{array}{l}\text { he left the world full; } \\
\text { here he finds it empty. } \\
(\mathrm{D}, 60)\end{array}$ & $\begin{array}{l}\text { everything else. He } \\
\text { was left the world } \\
\text { full, he finds it } \\
\text { empty. (T, 68) }\end{array}$ & $\begin{array}{l}\text { a universe that was } \\
\text { filled; he discovers the } \\
\text { void; ... (S, 47) }\end{array}$ \\
\hline
\end{tabular}

Ayant d'abord fait l'éloge de Descartes, Voltaire lui reproche à la fin de la lettre XIV de s'être laissé aller à ce qu'il appelle un "esprit de système", faisant ainsi allusion à une philosophie dogmatique et sclérosée. La version anglaise de 1733 interprète hardiment le blâme en invectivant la propension à se perdre dans des hypothèses sans suffisamment se tenir aux faits que décèle avec clarté l'empirisme scientifique pratiqué par Newton ${ }^{12}$. Les traductions modernes affaiblissent considérablement la critique qui se noie dans une lecture plus floue qui rend mal la notion péjorative d' "esprit de système".

\begin{tabular}{|c|c|c|}
\hline \multicolumn{3}{|c|}{$\begin{array}{l}\text {... cependant il [Descartes] abandonna à la fin ce guide [la géométrie] et se } \\
\text { livra à l'esprit de système. Alors sa philosophie ne fut plus qu'un roman } \\
\text { ingénieux, et tout au plus vraisemblable pour les ignorants. }(\mathrm{GF}, 150)\end{array}$} \\
\hline \multicolumn{3}{|c|}{$\begin{array}{l}\text { Nevertheless he at last abandon'd this Guide [Geometry], and gave entirely } \\
\text { into the Humour of forming Hypotheses; and then Philosophy was no more } \\
\text { than an ingenious Romance fit only to amuse the Ignorant. }(1733,65)\end{array}$} \\
\hline $\begin{array}{l}. . \text { he abandoned that } \\
\text { guide [geometry] in } \\
\text { he end, however, } \\
\text { and gave himself up } \\
\text { to the systematizing } \\
\text { pirit. From then on, } \\
\text { his philosophy was no } \\
\text { more than an ingenious }\end{array}$ & $\begin{array}{l}\ldots \text { he f } \\
\text { abando } \\
\text { [mather } \\
\text { himself } \\
\text { system } \\
\text { philoso } \\
\text { more th } \\
\text { novel, }\end{array}$ & $\begin{array}{l}\text { this guide } \\
\text { and } \\
\text { d to the } \\
\text { system. At } \\
\text { is philosophy } \\
\text { more than an } \\
\text { ale, at more }\end{array}$ \\
\hline
\end{tabular}

12 Voir entre autres d'Alembert qui précisera dans son Discours préliminaire de l'Encyclopédie (1751) : “Ce n'est donc point par des hypothèses vagues et arbitraires que nous pouvons espérer connaître la nature, c'est par l'étude réfléchie des phénomènes [...] plus on diminue les principes d'une science, plus on leur donne d'étendue; [...] Cette réduction [...] constitue lé véritable esprit systématique, qu'il faut bien se garder de prendre pour l'esprit de système". (Paris: Vrin, 2000, 93). 


\begin{tabular}{|l|l|l|}
\hline $\begin{array}{l}\text { romance, at best } \\
\text { seeming probable to the } \\
\text { ignorant. }(\mathrm{D}, 64)\end{array}$ & $\begin{array}{l}\text { best only plausible to } \\
\text { ignoramuses. }(\mathrm{T}, 71)\end{array}$ & $\begin{array}{l}\text { merely plausible for } \\
\text { ignorant people. }(\mathrm{S}, 50)\end{array}$ \\
\hline
\end{tabular}

Les "égarements" de Descartes enfin sont dignes de l'auteur du Discours de la méthode : "il se trompa, mais ce fut avec méthode", écrit hardiment Voltaire. He deceived himself tient à la fois de l'égarement et de la déconvenue. Seules la version de 1733 et celle de Tancock maintiennent l'errance méthodique, qui se fait platement systématique chez Dilworth et Steiner.

\begin{tabular}{|c|c|c|}
\hline- & - & $\begin{array}{l}\text { Mais ce n'est point } \\
\text { ents : il se trompa, } \\
(\mathrm{GF}, 151)\end{array}$ \\
\hline oica & , 65-66) & 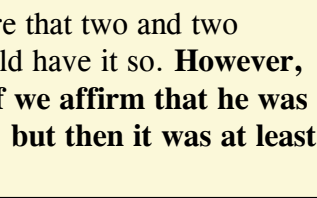 \\
\hline $\begin{array}{l}\text { e carried his errors in } \\
\text { etaphysics so far as } \\
\text { assert that two and } \\
\text { vo make four only } \\
\text { ecause God was willed } \\
\text { so. But it is not too } \\
\text { uch to say that he } \\
\text { as admirable even in } \\
\text { is aberrations. When } \\
\text { was wrong, at least } \\
\text { e was systematically } \\
\text { rong, and with logical } \\
\text { herence. (D, 64) }\end{array}$ & $\begin{array}{l}\text { He carried his } \\
\text { metaphysical errors to } \\
\text { the point of maintaining } \\
\text { that two and two only } \\
\text { make four because God } \\
\text { has willed it so. But it } \\
\text { is not too much to say } \\
\text { that he was admirable } \\
\text { even in his errors. } \\
\text { He was wrong, but at } \\
\text { least methodically and } \\
\text { with a logical mind; ... } \\
(\mathrm{T}, 72)\end{array}$ & $\begin{array}{l}\text { He pushed his } \\
\text { metaphysical mistakes } \\
\text { so far as to insist that } \\
\text { two and two make } \\
\text { four only because God } \\
\text { wished it thus. Yet } \\
\text { it is not too much } \\
\text { to say that even in } \\
\text { his mistakes he is } \\
\text { admirable; he erred, } \\
\text { but it was at least } \\
\text { systematically and with } \\
\text { consistency }(S, 50)\end{array}$ \\
\hline
\end{tabular}




\section{Conclusion}

Quel enseignement peut-on tirer du cas que nous venons de brièvement évoquer? D'abord, comme l'a démontré Annie Brisset à propos de Darwin, qu'il est fécond de remettre en question "l'idée du texte original come foyer unique et stable du sens" (43). Les Lumières en particulier articulent une pensée mouvante qui s'exprime à travers une multitude de textes en perpétuelle mutation. Les ouvrages dits philosophiques de l'époque relèvent davantage de l'interrogation du monde, de la nature et de la société plutôt que de l'affirmation de connaissances établies. Les lire dans un isolement philologique est leur ôter le terreau fertile où elles s'expriment. Parfois ces textes, comme les Lettres anglaises ou encore le Dictionnaire philosophique, cette autre ouvre maîtresse de Voltaire, paraissent sous différents titres et différents états qui se jouent de la censure et témoignent d'une constante interrogation. Le sens qu'elles divulguent se cherche en outre à travers un continuum de textes multiples qui toujours dialoguent entre eux. Les Lettres anglaises révèlent en outre que la traduction prolonge le questionnement de la société dans un environnement culturel et temporel que texte source et texte cible ont en commun. Ce qu'Annie Brisset appelle "la simultanéité historique" (49) soude les textes écrits à une même époque et disparaît en revanche dans le cas des retraductions ultérieures qui ne portent plus en elles les résonances cognitives constitutives du sens. La voix énarrative du traducteur de 1733 fait retentir à Londres avec force ce qui doit être déguisé à Paris, conformément à l'entreprise philosophique de Voltaire; cette "richesse signifiante" pour parler comme Berman (5) s'étiole dans les traductions modernes qui, par une énarration prudente, éloignent paradoxalement le lecteur du texte d'origine. La célèbre expression des "belles infidèles" recouvre une réalité plus complexe qu'il n'y paraît quand il s'agit des textes philosophiques du XVIIIe siècle. Les libertés prises sont loin d'être gratuites et font apparaitre en filigrane des pratiques culturelles et historiques qui font sens. Les traductions anglaises de Rousseau, de La Mettrie ou de Voltaire divulguent par l'entremise d'une certaine emphase le projet 
illocutoire des textes originaux; tout comme les traductions françaises de Toland, de Collins ou de Hume portent en elles la marque d'une parole qui s'exprime au contraire dans la contrainte d'une censure qui fait apparaître en négatif la subversion d'une parole interdite. Amplification et concision expriment dans l'abondance et la retenue le projet même des Lumières qui proposent une réflexion impliquant une fondamentale remise en ordre de la société. Nos recherches nous ont convaincus du fait que les traductions d'époque sont pour la plupart du temps sous-estimées alors qu'elles offrent pourtant un outil indispensable à qui veut comprendre et analyser le phénomène complexe de la philosophie des Lumières. Dans notre optique, il s'agit moins de comparer sous vide un texte source immuable à une traduction forcément imparfaite mais plutôt, comme le propose Annie Brisset, "de faire apparaître les correspondances discursives, les résonances cognitives, les homologies épistémiques qui relient les productions entre elles dans un état de société" (63).

\section{Bibliographie}

\section{A. Ouvrages de Voltaire}

Mr. de Voltaire. Letters concerning the English Nation. London: C. Davis \& A. Lyon, 1733.

M.D.V***. Lettres écrites de Londres sur les Anglais et autres sujets. Basle [Londres: W. Bowyer], 1734.

M.D.V***. Lettres philosophiques. Amsterdam : Chez E. Lucas [Rouen: Jore], 1734.

The Works of M. de Voltaire translated from the French with Notes, historical and critical by T. Smollett, M.D. T. Francklin, M. A. and Others. London : Printed for J. Newbery [etc.], vol. 13, 1762. 
Lettres philosophiques. Edition critique, avec une introduction et un commentaire, par Gustave Lanson. Paris: E. Cornély, 1909. Paris: Hachette, 1915, 1924.

Philosophical Letters (Letters Concerning the English Nation). Translated, with an Introduction, by Ernest Dilworth. Minneapolis: Bobbs-Merrill, 1961. Mineola. New York: Dover Publications, 2003.

Letters on England. Translated with an Introduction by Leonard Tancock. London: Penguin Books, 1980 \& 2005.

Lettres philospohiques. Edition de Frédérc Deloffre. Paris: Gallimard (Folio Classique), 1986.

Letters concerning the English Nation. Edited with an Introduction and Notes by Nicholas Cronk. Oxford: Oxford University Press, 1994 \& 2009.

Lettres philosophiques. Derniers écrits sur Dieu. Présentés par Gerhardt Stenger. Paris: Garnier-Flammarion, 1996.

Lettres philosophiques. Edition d'Olivier Ferret et Antony McKenna. Paris: Classiques Garnier, 2000.

Philosophical Letters. Or, Letters Regarding the English Nation. Edited, with an Introduction, by John Leigh. Translated by Prudence L. Steiner. Indianapolis / Cambridge: Hackett Publishing Company, 2007.

\section{B. Ouvrages secondaires}

Berman, Antoine. "La retraduction comme espace de traduction." Palimpsestes, 4 (1990): 1-7.

Brisset, Annie. "Retraduire ou le corps changeant de la connaissance. Sur l'historicité de la traduction." Palimpsestes, 15 (2004): 39-68.

Brown, Harcourt. "The Composition of the 'Letters concerning the English Nation'”. The Age of the Enlightenment: Studies presented to Theodore Besterman Ed. Barber, W.H. and others. Edinburgh: Oliver and Boyd, 1967. 15-34. 
Copeland, Rita. Rhetoric, Hermeneutics and Translation in the Middle Ages. Academic Traditions and Vernacular Texts. Cambridge: Cambridge University Press, 1991.

Cronk, Nicholas. "The 'Letters concerning the English Nation' as an English work reconsidering the Harcourt Brown thesis.” SVEC, 10 (2001): 226-239.

Genette, Gérard. Palimpsestes. Paris: Seuil, 1982.

. Seuils. Paris: Seuil, 1987.

Inventaire Voltaire. Sous la direction de Goulemot, Jean, Magnan, André \& Masseau, Didier. Paris: Gallimard, 1995.

Jooken, Lieve \& Rooryck, Guy. “John Locke ou la traduction de l'entendement “. Ton Naaijkens (ed.), Event or incident. On the Role of Translations in the Dynamics of Cultural Exchange 3 Ed Ton Naaijkens. Bern: Peter Lang, 2010. 211-246

Lee, J. Patrick. "The unexamined premise: Voltaire, John Lockman and the myth of the English Letters." SVEC, 10 (2001): 340-270.

McMurran, Mary Helen. The spread of novels. Translation and prose fiction in the eighteenth century. Princeton and Oxford: Princeton University Press, 2010.

Rooryck, Guy \& Jooken, Lieve. "Le péritexte des traductions anglaises du Discours sur les Sciences et les Arts de Jean-Jacques Rousseau: la voix énarrative du traducteur". META, 58.3 (2013): 589-606.

Recebido em: 26/08/2018

Aceito em: 30/11/2018

Publicado em janeiro de 2019

Guy Rooryck. E-mail: Guy.Rooryck@UGent.be

ORCID: https://orcid.org/0000-0002-6810-0345

Lieve Jooken. E-mail: Lieve.Jooken@UGent.be

ORCID: https://orcid.org/0000-0002-7761-4145 